\title{
Relationship Between Ferritin Status and the Incidence of Hypogonadism in Children with Transfusion-dependent Thalassemia
}

\author{
Muchaimin Buntara ${ }^{\mathrm{a}}$, Olga Rasiyanti Siregar ${ }^{\mathrm{b}}$, Karina Sugih Arto ${ }^{\mathrm{a}, \mathrm{b}, *}$ \\ Iminbuntara@gmail.com \\ Resident of Department of Child Health, Faculty of Medicine, University Of Northren Sumatra /Adam Malik Hospital, Medan \\ ${ }^{a}$ Haematology Consultant of Department of Child Health, ${ }^{b}$ Endocrinology Consultant of Department of Child Health Medical School, \\ University Of Northren Sumatra / Adam Malik Hospital, Medan
}

\begin{abstract}
This study aims to examine the relationship between ferritin status and the incidence of hypogonadism in children with transfusion dependent thalassemia. A cross-sectional study was conducted on thalassemia patients at Haji Adam Malik General Hospital Medan from March to May 2021. Each subject was interviewed and blood was drawn before transfusion for laboratory examination. The data was analysed using the Mann-Whitney test and the Fisher Exact test. From 31 subjects who had met the inclusion and exclusion criteria, mean ferritin levels was 1684.39 $\mathrm{ng} / \mathrm{ml}$. The results of gonadal hormones examination, such as progesterone, estrogen and testosterone were low in 17 patients $(\mathrm{p}<0.001)$. There was a significant association between the ferritin status and hypogonadism in $\beta$ thalassemia major children at Haji Adam Malik General Hospital Medan.
\end{abstract}

Keywords: thalassemia, ferritin status, hypogonadism

\section{Introduction}

Thalassemia is the most common genetic blood disorder in the world due to lack of hemoglobin-forming substances, resulting inadequate production of normal red blood cells. Approximately 300,000 to 500,000 newborns suffer from severe hemoglobin abnormalities, while 50,000 to 100,000 children died from beta thalassemia. Most mortality cases (80\%) contributed by developing countries. Thalassemia Center, Department of Pediatrics, Faculty of Medicine University of Indonesia and Dr. Cipto Mangunkusumo General Hospital showed 1,723 patients are mostly on age 11-14 years old (Indonesia ministry of health., 2018).

Regular blood transfusion is one of therapies for beta thalassemia major. Complications generally occur due to accumulation of iron in the heart, liver, and endocrine organs including the pancreas, thyroid, parathyroid, and pituitary glands, resulting organ abnormalities.

Hypogonadism is the most common endocrine complication. It affects $70-80 \%$ of patients with beta thalassemia major. It is due to iron deposits (ferritin) in the gonads, pituitary gland or both. Prolonged conditions can lead to puberty disorders. Several studies showed that high serum ferritin level during puberty $(>2,500 \mathrm{ng} / \mathrm{ml})$ increases the risk of developing hypogonadism (Srisukh S et al., 2016).

The incidence of hypogonadism is often associated with transfusion-dependent thalassemia. Thus, it must be considered as a possible risk factor of puberty disorders. This study aims to examine the relationship between ferritin status and the incidence of hypogonadism in children with transfusion dependent thalassemia.

\section{Methods}

\subsection{Subject and Methods}

An analytical cross-sectional study was conducted. The objective is to examine the relationship between ferritin status and the incidence of hypogonadism in children with transfusion dependent thalassemia. Study was conducted at paediatric thalassemia one day care and ward of H. Adam Malik General Hospital Medan from March to May 2021. 
The inclusion criteria were patients with beta thalassemia major aged 9 to 18 years old, who sought treatment at the Paediatric Haematology-Oncology Division of the H Adam Malik General Hospital Medan and received packed red cell (PRC) blood transfusions at least 10 times and regular blood transfusions.

Subjects who met the inclusion criteria were fully informed and had given consent by parents or guardians for underage subjects. Baseline data were obtained from interview with subjects or the guardians, including the frequency of blood transfusions and the iron chelation therapy used. Subjects' blood was drawn before transfusion for laboratory examination, including complete blood count, ferritin and gonadal hormone levels such as estrogen and progesterone in female patients, and testosterone in male patients. The data would be presented in tabular form and analysed. This study was approved by the Ethics Committee of the Faculty of Medicine, University Of Northren Sumatra / Haji Adam Malik General Hospital in Medan.

\subsection{Statistical Analysis}

Statistical analysis was performed using Microsoft Excel® and SPSS version 25.0 with significance value of $\mathrm{p}<0.05$. Univariate described analysis of categorical data (frequency and percentage) and numerical data (mean, standard deviation, median, minimum and maximum values). Bivariate described analysis of relationship using Mann Whitney test. The ferritin level data was categorised into 2 categories with a cut off value of $1,000 \mathrm{ng} / \mathrm{ml}$ which were hyperferritinemia and normal ferritin levels. Ferritin status categorical data on the incidence of hypogonadism was analysed using Fischer exact test.

\section{Result}

Thirty-one children with beta thalassemia major consisting 22 male (71\%). The mean age of the subjects is 13.42 years. Subjects with poor nutritional status were 14 (45.2\%). Twenty-three subjects $(74.1 \%)$ suffered from moderate anemia $(\mathrm{Hb}$ levels $7-9 \mathrm{~g} / \mathrm{dl})$ prior blood transfusion. Twenty-one $(67.8 \%)$ subjects received blood transfusions every 2 weeks.

The laboratory examination showed the mean ferritin levels of $1684.39 \mathrm{ng} / \mathrm{ml}$. The lowest level was 729 $\mathrm{ng} / \mathrm{ml}$ and the highest was $>2,000 \mathrm{ng} / \mathrm{ml}$. Hyperferritinemia occurred in 23 subjects (74.2\%). Hormonal examination showed 17 (54.8\%) subjects suffered hypogonadism.

Table 1. Subject characteristics.

\begin{tabular}{|c|c|}
\hline Characteristics & $\mathrm{n}=31$ \\
\hline \multicolumn{2}{|l|}{ Gender $(\%)$} \\
\hline Male & $22(71)$ \\
\hline Female & $9(29)$ \\
\hline \multicolumn{2}{|l|}{ Age } \\
\hline Mean (SD) & $13,42(3.28)$ \\
\hline Median (min-max) & $14(9-18)$ \\
\hline \multicolumn{2}{|l|}{ Nutrition status, n (\%) } \\
\hline Malnutrition & $14(45,2)$ \\
\hline Well nourished & $17(54.8)$ \\
\hline \multicolumn{2}{|l|}{$\mathrm{Hb}$ level pre-transfusion } \\
\hline $9-10 \mathrm{~g} / \mathrm{dl}$ & $3(9.6)$ \\
\hline $7-9 \mathrm{~g} / \mathrm{dl}$ & $23(74.1)$ \\
\hline$<7 \mathrm{~g} / \mathrm{dl}$ & $5(16.2)$ \\
\hline \multicolumn{2}{|l|}{ Frequency of blood transfusion } \\
\hline Every 2 weeks & $21(67.8)$ \\
\hline Every 3 weeks & $9(29)$ \\
\hline Every 4 weeks & $1(3.2)$ \\
\hline \multicolumn{2}{|l|}{ Ferritin, ng/ml } \\
\hline Mean (SD) & $1684.39(501.3)$ \\
\hline Median (min-max) & $2000(729-2000)$ \\
\hline Hyperferritinemia (>1,000 ng/ml), n (\%) & $23(74.2)$ \\
\hline Normal ferritin $(\leq 1,000 \mathrm{ng} / \mathrm{ml}, \mathrm{n}(\%)$ & $8(25.8)$ \\
\hline \multicolumn{2}{|l|}{ Organomegaly, n (\%) } \\
\hline Hepatomegaly & $25(80.6)$ \\
\hline Hepatosplenomegaly & $6(19.4)$ \\
\hline \multicolumn{2}{|l|}{ Hypogonadism, n (\%) } \\
\hline Yes & $17(54.8)$ \\
\hline No & $14(45.2)$ \\
\hline
\end{tabular}


Table 2. Gonadal hormone levels based on gender.

\begin{tabular}{lcc}
\hline & Male $(\mathrm{n}=22)$ & Female $(\mathrm{n}=9)$ \\
\hline Estrogen, ng/dl & & $30.61(21, .37)$ \\
Mean (SD) & & $19.2(13.2-65.3)$ \\
Median (min-max) & & $6(66.7)$ \\
$<20.4 \mathrm{ng} / \mathrm{dl}, \mathrm{n}(\%)$ & $3(33.3)$ \\
$\geq 20.4 \mathrm{ng} / \mathrm{dl}, \mathrm{n}(\%)$ & & $0.99(0.45)$ \\
Progesterone, ng/dl & & $0.74(0.62-1.73)$ \\
Mean (SD) & & $6(66.7)$ \\
Median (min-max) & & $3(33.3)$ \\
$<1 \mathrm{ng} / \mathrm{dl}, \mathrm{n}(\%)$ & $1.53(2.35)$ & \\
$\geq 1 \mathrm{ng} / \mathrm{dl}, \mathrm{n}(\%)$ & $0.12(0.05-7.49)$ & \\
Testosterone, ng/dl & $11(50)$ & \\
Mean (SD) & $11(50)$ & \\
Median (min-max) & & \\
$<0.1 \mathrm{ng} / \mathrm{dl}, \mathrm{n}(\%)$ & & \\
$\geq 0.1 \mathrm{ng} / \mathrm{dl}, \mathrm{n}(\%)$ & & \\
\end{tabular}

Estrogen levels showed mean of $30.61 \mathrm{ng} / \mathrm{dl}$ in female subjects. Six children (66.7\%) showed estrogen levels below normal. Progesterone showed an average of $0.99 \mathrm{ng} / \mathrm{dl}$. A total of 6 children $(66.7 \%)$ with progesterone levels below normal. Testosterone levels show mean of $1.35 \mathrm{ng} / \mathrm{dl}$ in male subjects. Eleven children (50\%) showed abnormal testosterone level.

Table 3. Association between ferritin status and incidence of hypogonadism.

\begin{tabular}{|c|c|c|c|c|c|}
\hline & & \multirow{2}{*}{$\mathrm{n}$} & \multicolumn{2}{|c|}{ Hypogonadism } & \multirow[b]{2}{*}{$\mathrm{p}^{*}$} \\
\hline & & & Yes & No & \\
\hline \multicolumn{6}{|l|}{ All subjects } \\
\hline Ferritin, ng/ml & $\begin{array}{l}>1000 \mathrm{ng} / \mathrm{ml} \\
\leq 1000 \mathrm{ng} / \mathrm{ml}\end{array}$ & $\begin{array}{l}23 \\
8\end{array}$ & $\begin{array}{l}17(73.9) \\
0\end{array}$ & $\begin{array}{l}6(26.1) \\
8(100)\end{array}$ & $<0.001$ \\
\hline \multicolumn{6}{|l|}{ Male } \\
\hline Ferritin, ng/ml & $\begin{array}{l}>1000 \mathrm{ng} / \mathrm{ml} \\
\leq 1000 \mathrm{ng} / \mathrm{ml}\end{array}$ & $\begin{array}{l}16 \\
6\end{array}$ & $\begin{array}{l}11(68.8) \\
0\end{array}$ & $\begin{array}{l}5(31.2) \\
6(100)\end{array}$ & 0.012 \\
\hline $\begin{array}{l}\text { Female } \\
\quad \text { Ferritin, ng/ml }\end{array}$ & $\begin{array}{l}>1000 \mathrm{ng} / \mathrm{ml} \\
\leq 1000 \mathrm{ng} / \mathrm{ml}\end{array}$ & $\begin{array}{l}7 \\
2 \\
\end{array}$ & $\begin{array}{l}6(85.7) \\
0\end{array}$ & $\begin{array}{l}1(14.3) \\
2(100)\end{array}$ & 0.043 \\
\hline
\end{tabular}

* Fischer's Exact

By categorizing the ferritin value based on the cut off value $(1000 \mathrm{ng} / \mathrm{ml})$, it can be seen from 23 children with ferritin levels $>1000 \mathrm{ng} / \mathrm{ml}$ (hyperferritinemia) there are 17 children (73.9\%) with hypogonadism. Meanwhile, of 8 children with normal ferritin levels $(\leq 1000 \mathrm{ng} / \mathrm{mL})$, none showed hypogonadism. Using Fischer's Exact test showed that there was a significant relationship between ferritin status and hypogonadism $(\mathrm{p}<0.001)$.

\section{Discussion}

The number of male subjects is more than female subjects. This study supports previous study in 2010, which stated that from 50 thalassemia $\beta$ major patients, 29 were male patients and 21 were female patients (Hassan TH., 2010). A study also showed 58\% of the thalassemia $\beta$ major patients were male in 2017 (Abosdera et al., 2017). Most subjects in this study were well-nourished. A study on 2019 showed that 6 subjects were wellnourished while 4 subjects were suffering from malnutrition (Permatasari et al., 2019). In thalassemia patients, haemolysis resulting chronic anaemia and hypoxia. Thus, cells are lack of nutrition, resulting in growth problems. Anaemia and hepatosplenomegaly also have contribution to loss of appetite condition. This condition leads to low intake of macronutrient and micronutrient. Thus, it is common that thalassemia patients suffering from malnutrition.

Guidelines Thalassemia International Federation (TIF) in 2014 suggested the implementation of regular transfusions can be done every 2 to 5 weeks. Repeat transfusion may cause excessive iron absorption (iron overload) due to ineffective erythropoiesis. Hyperferritinsemia occurred in 23 subjects $(74.2 \%)$. This was caused by regular blood transfusion therapy since the patient is diagnosed with thalassemia. This supports previous study conducted with Sanglah General Hospital Denpasar study in 2011 (A Made et al., 2011). Other study in Africa also showed the 
effect of regular transfusion to the occurrence of iron overload (Jabbar D.A et al., 2007). Low compliance in medications and the availability of drugs can be the cause of high levels of ferritin levels in thalassemia patients in $\mathrm{H}$ Adam Malik General Hospital. A study in 2016 stated the lower the compliance of iron chelation therapy, the higher ferritin levels (Fitri SV., 2016).

A Study at the Al-Wattani Hospital in Nablus showed that hypogonadism is the main cause of endocrinopathy and represented by $46.7 \%$ among 75 patients with thalassemia beta major, both primary and secondary hypogonadism (Daraghmeh $\mathrm{N}$ et al., 2016). Other cross-sectional studies were carried out by four Palestinian districts: Al-Khalil, Ario (Jericho), Ramallah and Jenin found that the level of the incidence of hypogonadism is $47 \%$ of cases among 61 thalassemia beta mayor patients (Dumaidi K et al., 2015).

There is association between hyperferritinemia and the incidence of hypogonadism in children with transfusion-dependent thalassemia $(\mathrm{p}<0.001)$. This supports previous study conducted by a study in 2016 , which reported that there was a significant association between serum ferritin on the incidence of hypogonadism in major thalassemia patients (70-80\%) (Srisukh et al., 2016).

The result of this study showed that ferritin levels had significant association with the incidence of hypogonadism in male subjects $(\mathrm{p}=0.012)$. Initial study in Oman showed the prevalence of hypogonadism due to transfusion was $73.3 \%$ and $50 \%$ of them were hypogonadotropic hypogonadism (Mula-Abed WA et al., 2014). There was also significant association between ferritin levels of the incidence of hypogonadism in female subjects $(\mathrm{p}=0.043)$. This supports previous study in Egypt and showed FSH serum, LH and estrogen are significantly lower in the major beta thalassemia group compared to group control (Hegazi M et al., 2013). A study in 2017 also reported a significant decrease in FSH, LH, estrogen and progesterone compared to control (Yenzeel JH, Salih LA., 2017).

A serum ferritin measurement has correlation with iron deposits in the body (liver iron concentration) with a correlation coefficient ranging from 0.5-0.7. This can be used as a reference that there is association between ferritin status and the incidence of hypogonadism in transfusion-dependent thalassemia patients.

The limitations of this study are not taken into account about the condition of ferritin level fluctuations due to iron chelation therapy on the same subject so that the levels of gonad hormone can be compared. More study samples in the 9-year age group can also provide bias, which the population is in the beginning of puberty. At this age, sexual hormone levels begin to increase. Thus, it is not possible to eliminate bias of hypogonadism.

\section{Conclusion}

There is a significant association between ferritin status and the incidence of hypogonadism in children with the transfusion-dependent thalassemia with $\mathrm{p}=0.001$ at the $\mathrm{H}$. Adam Malik General Hospital in Medan. Results of the gonad hormone examination namely progesterone, estrogen and testosterone showed 17 children (54.8\%) with hypogonadism conditions. Based on ferritin levels, there were 17 children $(73.9 \%)$ with hyperferritinemia undergoing hypogonadism condition, while of 8 children with normal ferritin levels. In male, there is a significant association between ferritin status and the incidence of decreasing testosterone hormone levels $(p=0.012)$ while in female, there is a significant association between ferritin status and the incidence of decreasing the levels of estrogen and progesterone hormones $(\mathrm{p}=0.043)$.

\section{Acknowledgements}

The author thanks to all clinical staff of Pediatric Hematology Oncology and Pediatric Endocrinology, University of Northern Sumatra, who were involved and contributed for the completion of this study.

\section{References}

A Made, A Ketut. Growth Profile, Pre-Transfusion Haemoglobin, Ferritin Levels, and Bone Age in Children with Thalassemia Major. Sari Pediatri, 2011; 13:1-6.

Abosdera MM, Almasry AE, Abdel-Moneim ES. Coagulation Defects in Thalassemia Patients. Pediatr Neonatol. 2017; 58(5):421-4.

Arijanty L, Nasar SS. Nutritional Problems in Thalassemia. Sari Pediatri. 2003; 5(1): 21-6.

Belhoul K, Bakir M, Kadhim A. Prevalence of Iron Overload Complications Among Patients with B-Thalassemia Major Treated at Dubai Thalassemia Centre. Annals of Saudi medicine. 2013; 33(1); 18-21 
Bronspiegel-Weintrob N, Olivieri N, Tyler B, Andrews D, Freedman M, Holland F. Effect of Age at the Start of Iron Chelation Therapy on Gonadal Function in $\beta$-Thalassemia Major. New Eng J of Medicine. 2010; 323(11):713-9.

Cappellini MD, Cohen A, Porter J, Taher A, Viprakasit V. Guidelines for the Management of Transfusion Dependent Thalassaemia. 3rd ed. Nicosia, Cyprus: Thalassemia International Federation.2014.

Daraghmeh, N. Growth and endocrine function in thalassemia major in childhood and adolescence. Journal of endocrinological investigation, 2016. 33(1), 61-8.

Dumaidi K, Al-Jawabreh A, Al-Assi S, Karmi, B. Assessment of Gonadal and Thyroid Function for Children Transfusion-Dependent- $\beta$ Thalassemia Patients in Palestine. Jordan Medical Journal, 2015; 171(3191), 1-10.

Fitri SV. Relationship between Adherences to Chelation Therapy with Serum Ferritin Levels in Beta-Thalassemia Patients in Children in dr. M. Djamil Padang General Hospital in 2010-2014. Universitas Andalas. 2016.

Hassan, T.H. Protein C levels in Beta Thalassemia Major Patients in the East Nile Delta of Egypt. Egypt: Paediatric and Clinical Pathology Department, Zagazig University. 2010

Hegazi M, Obada M. Elsheashaey A. Effect of Iron Overload on Function of Endocrine Glands in Egyptian Beta Thalassemia Patients." Journal of Applied Sciences Research. 2013. 9(8): 4656-62

Jabbar DA, Davison G, Muslin AJ. Getting the iron out: Preventing and Treating Heart Failure in Transfusion Dependent Thalassemia. Cleveland Clinic Journal of Medicine. 2007; 74(11):807-16.

Jandl JH. Hypochromic anaemia and disorders of iron metabolism. In Jandl JH eds Blood Pathophysiology 1st edition. Boston Blackwell Scientific Publication.2001;121-4, 131.

Khan H, Kamran M, Ubaidullah, Masood T, Ahmed J, Shah S, Taj AS. Hypogonadism in Multiply Transfused $\beta$ - Thalassemia Syndrome Patients. Adv Basic Med Sci. 2017;1(2):55-60

Moeryono H, Subroto F, Suryansyah A. Late Puberty in Thalassemia Children in Harapan Kita Hospital Jakarta. Sari Pediatri. 2016;14(3):162.

Mula-Abed WA, Hashmi HA, Mushlahi MA, Muslahi HA, Lamki MA. Prevalence of Endocrinopathies in Patients with Beta-Thalassemia Major -a Cross-Sectional Study in Oman. Oman Medical Journal. 2014;23(4):1-6.

National Guidelines for Thalassemia Management Medical Services. Decree of the Indonesia's Ministry of Health Indonesia no HK.01.07/MENKES/1/2018.

Permatasari T, Riyanti R, Wisudanti D. Relationship between Ferritin Levels and Malondialdehyde in Beta Major Thalassemia Patients in dr. Soebandi Jember General Hospital. Universitas Jember. 2019.

Shalitin S, Carmi D, Weintrob N. Serum Ferritin Level as a Predictor of Impaired Growth and Puberty in Thalassemia Major Patients. European Journal Haematology. 2005. 13(74):93-100.

Srisukh S, Ongphiphadhanakul B, Bunnag P. Hypogonadism in Thalassemia Major Patients. J Clin Transl Endocrinol. 2016;5:42-5.

Wahidiyat I. Thalassemia and its Problems Indonesia. Sari Pediatri. 2016;5(1):2.

Yenzeel JH, Salih LA. Effect of Beta- Thalassemia Major on Reproductive Hormones Levels and Ovarian Status in Sample of Iraqi Female. I.J.S.N. 2017; 8(3) 2017:500-4 